\title{
Phenotypic and genetic characterization of bacteria isolated from diseased cultured sea cucumber Apostichopus japonicus in northeastern China
}

\author{
Hua $\mathrm{Li}^{1}{ }^{\text {, Guo Qiao }}{ }^{1}$, Jie-Quan Gu${ }^{1}$, Wei Zhou ${ }^{1}$, Qiang $\mathrm{Li}^{1}{ }^{1}$, Sung-Ho Woo ${ }^{2}$, \\ De-Hai Xu ${ }^{3}$, Soo-Il Park ${ }^{2, *}$ \\ ${ }^{1}$ Key Laboratory of Mariculture and Biotechnology, Agriculture Ministry, PRC, Dalian Fisheries University, \\ Dalian 116023, China \\ ${ }^{2}$ Department of Aquatic Life Medicine, Pukyong National University, Busan 608737, Republic of Korea \\ ${ }^{3}$ US Department of Agriculture, Agricultural Research Service, Aquatic Animal Health Research Laboratory, \\ Auburn, Alabama 36832, USA
}

\begin{abstract}
During the winter-spring from 2004 to 2006 in northeastern China cultured Japanese sea cucumber Apostichopus japonicus suffered from a serious disease. Clinical signs included swollen mouth, skin ulceration and massive mortality. Clinical samples taken during this period were studied. Thirty-one bacterial samples were isolated from diseased sea cucumbers and identified through biochemical tests, 16S rRNA gene sequence analysis and PCR amplification, followed by pathogenicity determination. The results showed that the 31 isolates belonged to the genera Vibrio $(64.5 \%)$, Shewanella $(12.9 \%)$, Serratia (12.9\%), Pseudoalteromonas $(6.4 \%)$ and Flavobacterium (3.2\%). The 3 prominent strains were Vibrio splendidus (41.9\%), Shewanella (12.9\%) and Serratia odorifera biogroup I (12.9\%). Pathogenicity tests demonstrated that 13 out of 31 isolates were pathogenic, including 8 strains of $V$. splendidus, 3 strains of Shewanella sp. and 2 strains of Pseudoalteromonas tetraodonis. The pathogenic $V$. splendidus showed the highest frequency of appearance. Median lethal dose $\left(\mathrm{LD}_{50}\right)$ values $(14 \mathrm{~d})$ of $V$. splendidus, Shewanella sp. and P. tetraodonis were 1.74 $\times 10^{7}, 7.76 \times 10^{6}, 7.24 \times 10^{7} \mathrm{CFU} \mathrm{g}{ }^{-1}$ body weight of sea cucumber, respectively. The virulences differed by species: Shewanella sp. > V. splendidus $>$ P. tetraodonis. This is the first report of Shewanella sp. virulence in sea cucumber.
\end{abstract}

KEY WORDS: Sea cucumber · Apostichopus japonicus $\cdot$ Bacterial pathogen $\cdot$ Vibrio splendidus $\cdot$ Shewanella sp. P Pseudoalteromonas tetraodonis

Resale or republication not permitted without written consent of the publisher

\section{INTRODUCTION}

The Japanese sea cucumber Apostichopus japonicus has become a prominent aquaculture species, with a production of more than $200000 \mathrm{t}$ in northeastern China in 2006, especially in Dalian (Deng et al. 2009). With the rapid development of the aquaculture industry, diseases cause 20 to $40 \%$ mortality of cultured sea cucumbers leading to heavy economic losses. Diseases of sea cucumbers usually occur at 4 to $15^{\circ} \mathrm{C}$ from January to April in northeastern China and juveniles appear to be more susceptible than adults.
The incidence of diseases and types of pathogens, including Vibrio splendidus (see Zhang et al. 2006), V. cyclitrophicus, V. harveyi, Arthrobacter protophormiae and Staphylococcus equorum (see Deng et al. 2009), for sea cucumbers has been described sporadically and differently. Becker et al. (2004) studied the skin ulceration disease of sea cucumber Holothuria scabra juveniles and observed bacteria on the lesions by means of scanning and transmission electron microscopy (SEM and TEM, respectively). Cytophaga-Flavobacterium-Bacteroides, Roseobacter sp., Bacteroides sp. and Jannaschia helgolandensis were detected and amplified by denaturing 
gradient gel electrophoresis (DGGE) (Becker et al. 2004). Six isolates obtained from the lesions of diseased sea cucumbers were identified as Vibrio sp. but the pathogenicity assays of isolates were not successful (Becker et al. 2004). It is commonly believed that this disease of sea cucumbers is due to bacterial infections; however, the agent that initiates the skin ulcerations has not been identified (Becker et al. 2004). Most of the studies mainly focused on isolation and identification of pathogens.

No information is available for the distribution, diversity and appearance of pathogens in cultured sea cucumbers in China. The objective of this study was to carry out a precise characterization of bacterial pathogens responsible for outbreaks that affected cultured sea cucumbers during the winter-spring period from 2004 to 2006 in northeastern China.

\section{MATERIALS AND METHODS}

Sampling and processing. Seventy-three sea cucumbers were collected from 11 farms located in the suburbs of Dalian in northeastern China during winter- spring from 2004 to 2006 whenever a disease case was reported (Table 1). Three moribund or newly dead sea cucumbers showing disease signs were collected for bacteriologic assays at each sampling time from these areas. All samples were transported to our lab at $4^{\circ} \mathrm{C}$ within $24 \mathrm{~h}$. The body weights of the sea cucumbers were 1.6-2.0 g (95\%) and 15.1-20.5 g (5\%).

The bacteria were isolated from surface mucus, skin ulcerations, coelomic fluid and viscera of sea cucumbers, as well as from the nets, water and sediment of culture areas. The growth media used were marine agar (MA, Difco), Tryptic Soy agar (TSA, Acumedia Manufacturers) and thiosulphate-citrate-bile saltsucrose agar (TCBS, Difco). All bacterial isolates were incubated at $25^{\circ} \mathrm{C}$ for 48 to $72 \mathrm{~h}$. While the prominent isolation ratio of a strain was more than $15 \%$, the strain would be considered to be the prominent strain based on the morphological characterization observed at the time of sampling. The prominent strains were purified and stored at $-80^{\circ} \mathrm{C}$ in nutrient broth $(\mathrm{NB}$, Becton Dickinson) with $10 \%$ glycerol (v/v) and kept at room temperature in one-half nutrient agar (NA, Difco, Becton Dickinson). The final concentration of sodium

Table 1. Bacterial isolates (total of 31 strains) from diseased sea cucumber during winter-spring from 2004 to 2006

\begin{tabular}{|c|c|c|c|c|}
\hline $\begin{array}{l}\text { Strain } \\
\text { no. }\end{array}$ & $\begin{array}{l}\text { Sampling } \\
\text { site }\end{array}$ & $\begin{array}{l}\text { Sampling } \\
\text { date }\end{array}$ & Disease signs & Bacterial origin \\
\hline AP401 & Dalian Bay & Jan 2004 & Rickets, viscera ejection, skin ulceration & Rearing water \\
\hline AP402 & Xia's farm & Jan 2004 & Rickets, viscera ejection, skin ulceration & Skin ulceration \\
\hline AP403 & Dalian Bay & Jan 2004 & Skin ulceration, shaking head, rickets & Sediment \\
\hline AP427 & Dalian Bay & Jan 2004 & Rickets, viscera ejection, skin ulceration & Rearing water \\
\hline AP428 & Dalian Bay & Jan 2004 & Rickets, viscera ejection, skin ulceration & Coelomic fluid \\
\hline AP504 & Changxing Island & Jan 2005 & Rickets & Coelomic fluid \\
\hline AP505 & Dalian Bay & Jan 2005 & Rickets & Skin ulceration \\
\hline AP506 & Changxing Island & Jan 2005 & Viscera ejection, skin ulceration, swollen mouth & Coelomic fluid \\
\hline AP507 & Changxing Island & Jan 2005 & Viscera ejection, skin ulceration, swollen mouth & Skin ulceration \\
\hline AP508 & Changxing Island & Jan 2005 & Viscera ejection, skin ulceration, swollen mouth & Skin ulceration \\
\hline AP509 & Dalian Bay & Feb 2005 & Skin ulceration, swollen mouth & Sediment \\
\hline AP526 & Dalian Bay & Jan 2005 & Rickets & Coelomic fluid \\
\hline AP610 & Jinzhou & Jan 2006 & Green skin & Intestines \\
\hline AP612 & Xinzaizi & Jan 2006 & Rickets skin ulceration, swollen mouth & Intestines \\
\hline AP613 & Jinzhou & Jan 2006 & Rickets, skin ulceration, swollen mouth & Intestines \\
\hline AP614 & Jinzhou & Jan 2006 & Green skin & Skin ulceration \\
\hline AP615 & Jinzhou & Jan 2006 & Green skin, swollen mouth & Intestines \\
\hline AP616 & Jinzhou & Feb 2006 & White skin, skin ulceration, swollen mouth & Coelomic fluid \\
\hline AP617 & Jinzhou & Feb 2006 & White skin, skin ulceration, swollen mouth & Body wall \\
\hline AP618 & Wafangdian & Mar 2006 & Yellow skin, skin ulceration, swollen mouth & Coelomic fluid \\
\hline AP619 & Wafangdian & Mar 2006 & Yellow skin, skin ulceration, swollen mouth & Coelomic fluid \\
\hline AP620 & Wafangdian & Mar 2006 & Viscera ejection, skin ulceration, swollen mouth & Body wall \\
\hline AP621 & Dalian Bay & Mar 2006 & Viscera ejection, skin ulceration, swollen mouth & Skin mucus \\
\hline AP622 & Dalian Bay & Mar 2006 & Viscera ejection, skin ulceration, swollen mouth & Coelomic fluid \\
\hline AP722 & Dalian Bay & Dec 2006 & Skin ulceration, & Skin ulceration \\
\hline AP623 & Dalian Bay & Apr 2006 & Skin ulceration, swollen mouth & Coelomic fluid \\
\hline AP624 & Changxing Island & Apr 2006 & Skin ulceration, swollen mouth & Coelomic fluid \\
\hline AP625 & Changxing Island & Mar 2006 & Skin ulceration, swollen mouth & Body wall \\
\hline AP629 & Jinzhou & Feb 2006 & White skin, skin ulceration, swollen mouth & Coelomic fluid \\
\hline AP630 & Jinzhou & Feb 2006 & Dark skin, skin ulceration, swollen mouth & Body wall \\
\hline AP631 & Wafangdian & Mar 2006 & Yellow skin, skin ulceration, swollen mouth & Body wall \\
\hline
\end{tabular}


chloride in media used in this study was $2 \%$ except in TCBS.

Identification of isolates. Three different methods were used to identify isolates.

Physiological and biochemical characterization: Reference strains used in this study were Vibrio harveyii ATCC 14126, V. anguillarum HUFP5001, V. vulnificus ATCC 29306, V. ordalii ATCC 33509, Edwardsiella ictaluri ATCC 33202, Shewanella marisflavi KCCM 41822, S. affinis KCTC 12234, S. waksmanii KCTC 12233 and $S$. aquimarina KCCM 41821 (abbreviations used: ATCC: American Type Culture Collection, Rockville, Massachusetts; KCCM: Korean Culture Center of Microorganisms; KCTC: Korean Collection for Type Cultures).

Pure cultures of isolated bacteria were identified by cell morphology and biochemical characterization criteria proposed by Bergey's Manual of Determinative Bacteriology (Krieg \& Hoit 1994) and Alapide-Tendencia \& Dureza (1997), Dong \& Cai (2001) and Yoon et al. (2004). To determine cell morphology pure cultures of isolated bacteria were cultured in TSBS at $27^{\circ} \mathrm{C}$ for $2 \mathrm{~h}$ and centrifuged at $1710 \times g$ for $5 \mathrm{~min}$. The pellet was collected and fixed in $2.5 \%$ glutaraldehyde. A $10 \mu \mathrm{l}$ aliquot of bacterial suspension was dripped onto a transmission electron microscopy (TEM) grid and allowed to adhere to the grid surface. The adhered bacteria were stained with $4 \%$ uranyl acetate for 1 min and observed by TEM (JEM-1200EX). Cells were further identified through the following physiological and biochemical tests: (1) a Gram stain to determine cell motility and morphology by means of phase-contrast microscopy after growing in marine broth 2216 (Difco, Becton Dickinson) for $24 \mathrm{~h}_{i}(2)$ cytochrome-oxidase; (3) oxidation-fermentation (O-F) medium of Hugh and Leifson (O-F test); (4) susceptibility to $150 \mu \mathrm{g}$ of vibriostatic agent $\mathrm{O} / 129 ;(5)$ growth in $1 \%$ peptone at 4,10 , 35 or $40^{\circ} \mathrm{C}$ (for $7 \mathrm{~d}$ ); (6) growth in $1 \%$ peptone at salt concentrations of $0,0.5,2,4,6,8$ or $10 \%$ (for $7 \mathrm{~d}$ ); (7) gas production from glucose; (8) indole and VogesProskauer tests; (9) arginine dihydrolase; (10) decarboxylation of lysine and ornithine; (11) nitrate-reduction; (12) acid production from arabinose, sucrose, lactose and mannose; (13): catalase $\left(3 \% \mathrm{H}_{2} \mathrm{O}_{2}\right)$, urease and gelatinase enzymatic activities; (14) Tween-80, starch and hemolysis of sheep and rabbit blood (blood agar base with $5 \%$ blood).

The isolates identified as the genus Vibrio were tested as described by Alsina \& Blanch (1994). All results obtained were used for numerical analysis and isolates were identified to species level based on their similarity with reference strains.

PCR amplification by primers for $V$. splendidus: All 15 strains similar to Vibrio splendidus in biochemical characterization were amplified by primers VSPN-F (target gene: 16S-23S rDNA intergenic spacers, IGS $^{0}$ ) and VSP.

To determine nuclear receptor (NR) in target genes (spnA, spnD) for Vibrio splendidus (Lee et al. 2002), DNA extraction and purification were carried out following the methods of Xu et al. (2005) with some modifications. The isolates were cultured in TSB with $2 \% \mathrm{NaCl}$ for $24 \mathrm{~h}$ at $25^{\circ} \mathrm{C}$. Cells were harvested by centrifugation $(150 \times g$, $10 \mathrm{~min}$ ) at $4^{\circ} \mathrm{C}$ and the pellets were washed 3 times with distilled water. The pellets were then suspended in distilled water and DNA was extracted by means of the TIANamp Bacteria DNA Kit (TIANGEN) following manufacturer's instruction. The DNA was purified by increasing the DNA washing times with Tris-ethylenediaminetetraacetic acid (TE) buffer.

Vibrio splendidus primers VSPN-F (5'-GAT TTA GTT AAA GCC AGA GC-3') and VSPN-R (5'-CCT GAT AAC TGT TTG CCG-3') were synthesized by Takara (Dalian, China) and used to amplify 240 or $294 \mathrm{bp}$ of PCR products. Thirty microliters used in the PCR system included $5 \mu \mathrm{l} 10 \times$ PCR buffer, $0.5 \mu \mathrm{l}$ dNTPs (10 mM of each dNTP), $2 \mu \mathrm{l} \mathrm{MgCl}_{2} \cdot 6 \mathrm{H}_{2} \mathrm{O}$ (25 mM), $1 \mu \mathrm{l}$ of each primer $(10 \mu \mathrm{M}), 20 \mathrm{ng}$ template,

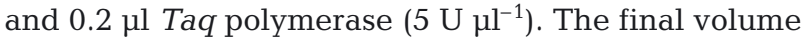
was adjusted with the addition of triple distilled water. The thermal cycle was run in a T3 thermal cycler (Biometra) at $95^{\circ} \mathrm{C}$ initially for $5 \mathrm{~min}, 35$ cycles of $95^{\circ} \mathrm{C}$ for $60 \mathrm{~s}, 55^{\circ} \mathrm{C}$ for $40 \mathrm{~s}$ and $72^{\circ} \mathrm{C}$ for $60 \mathrm{~s}$, and then $72^{\circ} \mathrm{C}$ for $10 \mathrm{~min}$. PCR products were applied to $1.5 \%$ agarose gel for electrophoresis and stained with $0.5 \mu \mathrm{g} \mathrm{l}^{-1}$ ethidium bromide.

16S rRNA genes sequence analysis: Genomic DNA was extracted as described above. Two universal bacteria primers (Weisburg et al. 1991), Eubac27F (5'-AGA GTI TGA TC(C/A) TGG CTC AG-3') and Eubac1492R (5'-TAC GG(C/T) TAC CTT GTT ACG ACT T-3') synthesized by Takara were used to amplify bacterial 16S rRNA genes. The PCR products were purified with Midi' Purification Kit (TIANGEN) according to the manufacturer's protocol and sequenced with a 3730 DNA Analyzer (ABI PRISM ${ }^{\mathrm{TM}}$ 3730XL DNA Sequencer, Shanghai Invitrogen Biotechnology). The partial 16S rRNA sequences were determined and deposited in the National Center for Biotechnology Information GenBank database under accession numbers GU569097, GQ 254504 and GQ 254506 to GQ 254516 (see Fig. 3). Phylogenetic analysis was conducted based on 16S rRNA sequences that were analyzed and aligned with DNA Star software. The Basic Local Alignment Search Tool (BLAST, www.ncbi.nlm. nih.gov) was used to search the Entrez database for homologous sequences and phylogenetic analysis. The software programs ClustalX 1.81 and MEGA 4.0 were used to analyze sequences and construct the phylogenetic trees (Tamura et al. 2007). An unrooted evolu- 
tionary tree was inferred using the neighbor-joining (N-J) tree algorithm. The resultant tree topologies were evaluated by bootstrap analysis of the N-J method based on 1000 replicates.

Pathogenicity assays. Two assays were used to determine pathogenicity of the bacterial isolates.

Pathogenicity assays of all isolates: Pathogenicity of the different bacterial isolates was determined in vivo following the protocols described by Toranzo et al. (1983) and Nieto et al. (1984). Trial sea cucumber juveniles (body weight, 1.6 to $2.0 \mathrm{~g}$ ) were obtained from Fangxing Farms and acclimated for $7 \mathrm{~d}$ before the pathogenicity assays. The water quality characteristics during the trials were: temperature 11 to $15^{\circ} \mathrm{C}, \mathrm{pH} 8.0$ to 8.4 and salinity 29.2 to 30.8 . To screen pathogens, pathogenicity assays were first performed at a higher bacterial concentration in triplicate with 32 sea cucumbers used in each group. Groups of 10 individuals were infected by intraperitoneal (i.p.) injection with $0.1 \mathrm{ml}$ bacterial suspensions at $4.3 \times 10^{9}$ to $8.6 \times 10^{9}$ cells ml $^{-1}$ per individual and the control group was injected with an equal volume of sterile sea water. The juveniles were observed daily for $14 \mathrm{~d}$ post bacterial challenge and mortalities were recorded. The experiments were repeated at $10^{9}$ cells $\mathrm{ml}^{-1}$ and $10^{8}$ cells $\mathrm{ml}^{-1}$, respectively. When the accumulated mortality of sea cucumber reached $100 \%$ at $14 \mathrm{~d}$ post challenge with $10^{9}$ cells $\mathrm{ml}^{-1}$ and more than $50 \%$ with $10^{8}$ cells $\mathrm{ml}^{-1}$, the bacterial isolate was considered pathogenic. The representative strains were selected for further study based on their virulence.

Pathogenicity assays of representative strains of bacterial isolates (median lethal dose 50\%): From the pathogenicity assays, Vibrio splendidus, Shewanella sp. and Pseudoalteromonas tetraodonis were identified as pathogens and representative strains were AP629, AP631 and AP722, respectively. Sea cucumber juveniles (body weight 1.6 to $2.0 \mathrm{~g}$ ) were injected intraperitoneally with $0.1 \mathrm{ml}$ of serial bacterial suspension that ranged from $10^{4}$ to $10^{9}$ cells $\mathrm{ml}^{-1}$. Groups of 10 sea cucumbers were inoculated and the same number was injected with equal volumes of sterile artificial seawater as controls. Mortalities were recorded daily and reisolation was done as described previously. In all challenge tests, mortality was considered to be caused by the bacterium if the inoculated bacterium was reisolated in pure culture from dead or moribund specimens. The median lethal dose $\left(\mathrm{LD}_{50}\right)$ was calculated using a modified Karber's method (Reed \& Muench 1938).

Antibiotic susceptibility assays. Susceptibility of representative isolates to antibiotics was conducted using a disk-diffusion technique as described by the National Committee for Clinical Laboratory Standard (NCCLS 2003, 2004). See Table 6 for a list of the antibiotics (supplied by Hang Zhou Tianhe Microorganism Teagent) and concentrations used.

\section{RESULTS}

\section{Signs of diseased sea cucumber}

Signs of diseased sea cucumbers included swollen mouth (Fig. 1A), viscera ejection (Fig. 1B), skin ulceration (Fig. 1C) and death (Fig. 1D). Thirty-one bacterial isolates were collected from diseased sea cucumbers from 11 farms with at least one showing clinical signs of disease.

\section{Characterization of bacterial isolates}

\section{Biochemical characterization}

Thirty-one isolates from the diseased sea cucumbers were identified to the genus according to the biochemical characterization (Table 2). All isolates were
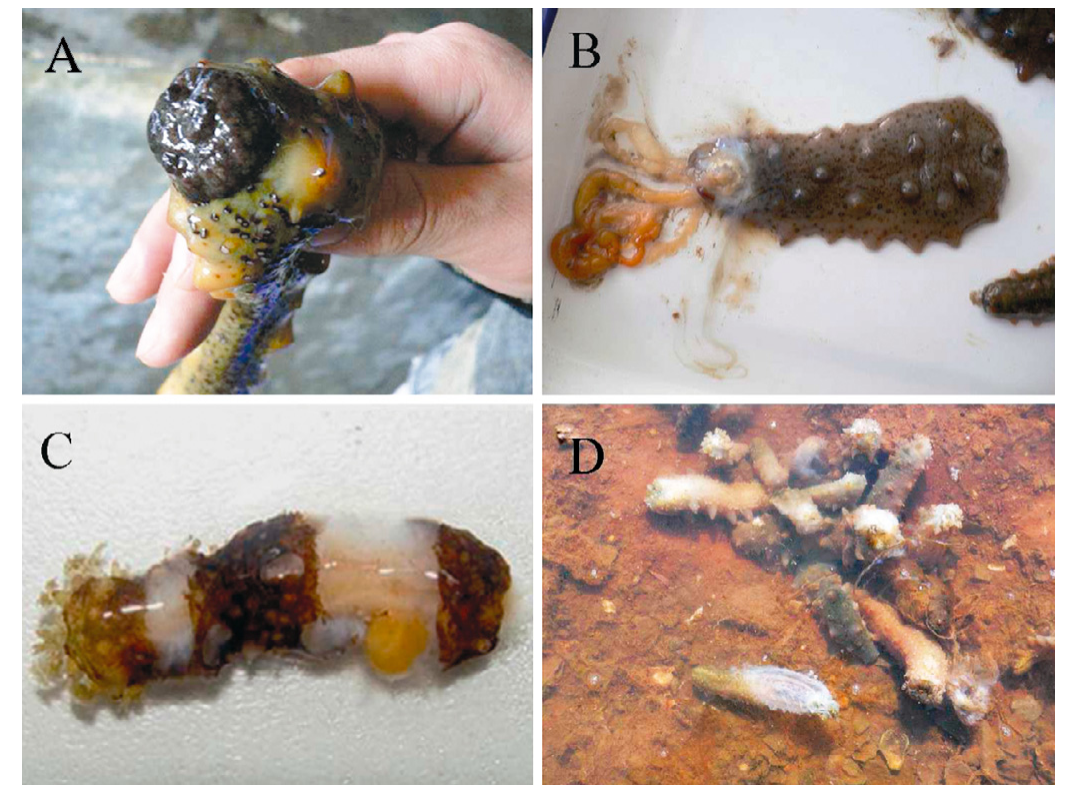

Fig. 1. Apostichopus japonicus. The main signs of diseased sea cucumbers in natural infection: (A) swollen mouth, (B) viscera ejection, (C) skin ulceration, (D) death 
Table 2. Main characterization for isolates to genus level. +: positive; -: negative; V: variable; O-F: oxidation-fermentation medium (F: fermentative; O: oxidative); O/129: 2,4-diamino-6,7-diiso-propylpteridine

\begin{tabular}{|c|c|c|c|c|c|}
\hline Test & Vibrio & Serratia & Shewanella & $\begin{array}{c}\text { Pseudo- } \\
\text { alteromonas }\end{array}$ & $\begin{array}{c}\text { Flavo- } \\
\text { bacterium }\end{array}$ \\
\hline Motility & + & + & + & V & - \\
\hline Flagellation & + & + & + & V & - \\
\hline O-F test & $\mathrm{F}$ & F & $\mathrm{F} / \mathrm{O}$ & $\mathrm{O}$ & $\mathrm{O}$ \\
\hline $\begin{array}{l}\text { Sensitivity to } \\
\text { O/129 }\end{array}$ & + & - & + & - & - \\
\hline Oxidase & + & - & + & + & + \\
\hline Gelatinase & V & V & + & + & V \\
\hline $\begin{array}{l}\mathrm{Na}^{+} \text {required } \\
\text { for growth }\end{array}$ & + & + & + & - & + \\
\hline $\mathrm{H}_{2} \mathrm{~S}$ production & - & + & + & - & - \\
\hline
\end{tabular}

tion from rhamnose; and for 5 strains (AP610, AP616, AP622, AP624, AP625) in acid production from rhamnose and fructose.

Biochemical characterization of strain AP508 was similar to Vibrio nereis except for acid production from cellobiose. Strains AP613 and AP620 were identical to $V$. orientalis and Listonella anguillarum (formally V. anguillarum). However, strains AP611, AP619 and AP615 could not been identified to other known species (Table 3).

Strains AP504, AP505, AP506 and AP507 showed identical biochemical characterization with Serratia odorifera biovar I (Table 3). Strains AP630 and

Gram-negative and belonged to the genera Vibrio, Shewanella, Serratia, Pseudoalteromonas or Flavobacterium (see Table 5). Under TEM, the representative species were observed to be long rods with flagellum for Serratia sp. (strain AP504, $4.71 \times 2.00 \mu \mathrm{m}$ ); blunt for Flavobacterium sp. (strain AP615, $4.86 \times 2.14 \mu \mathrm{m}$ ) and Pseudoalteromonas sp. (strain AP631, $5.98 \times 2.76 \mu \mathrm{m}$ ); and long rods, with a single polar flagellum for Shewanella sp. (strain AP629, $2.00 \times 1.14 \mu \mathrm{m}$ ) and Vibrio sp. (strain AP722, $1.72 \times 1.04 \mu \mathrm{m}$ ) (Fig. 2).

According to the biochemical characterization, 15 strains (AP401, AP402, AP403, AP610, AP612, AP614, AP616, AP617, AP618, AP621, AP622, AP623, AP624, AP625 and AP722) were similar to Vibrio splendidus, based mainly on growth at $4{ }^{\circ} \mathrm{C}$, a positive test result for lysine decarboxylase, arginine dihydrolase and gelatin hydrolysis, and negative test result for ornithine decarboxylase. Among them, 4 strains (strains AP618, AP621, AP722, AP623) were identical to V. splendidus. Differences from $V$. splendidus were noted for 4 strains (AP401, AP402, AP403, AP617) in acid production from fructose; for 2 strains (AP612, AP614) in acid produc-
AP631 were similar to Pseudoalteromonas tetraodonis (Table 4). Strains AP427, AP428, AP526 and AP629 were identified to genus Shewanella (Table 5).

\section{Genetic characterization}

All isolates were characterized biochemically and then representative strains of the same or different biochemical characterization were further identified genetically to the species level.

The 15 strains similar to Vibrio splendidus in biochemical characterization were amplified by VSPN-F and VSPN-R primers. The PCR results showed that 9 strains (AP402, AP403, AP610, AP612, AP618, AP621, AP622, AP624 and AP722) produced a band of 294 bp, with strain AP621 also producing a second band of $240 \mathrm{bp}$.

The phylogenetic analysis based on 16S rRNA gene sequences of the 13 representative strains is presented in Figs. 3 to 5. Partial 16S rRNA gene sequences of approximately $1000 \mathrm{bp}$, excluding primers, were ob-
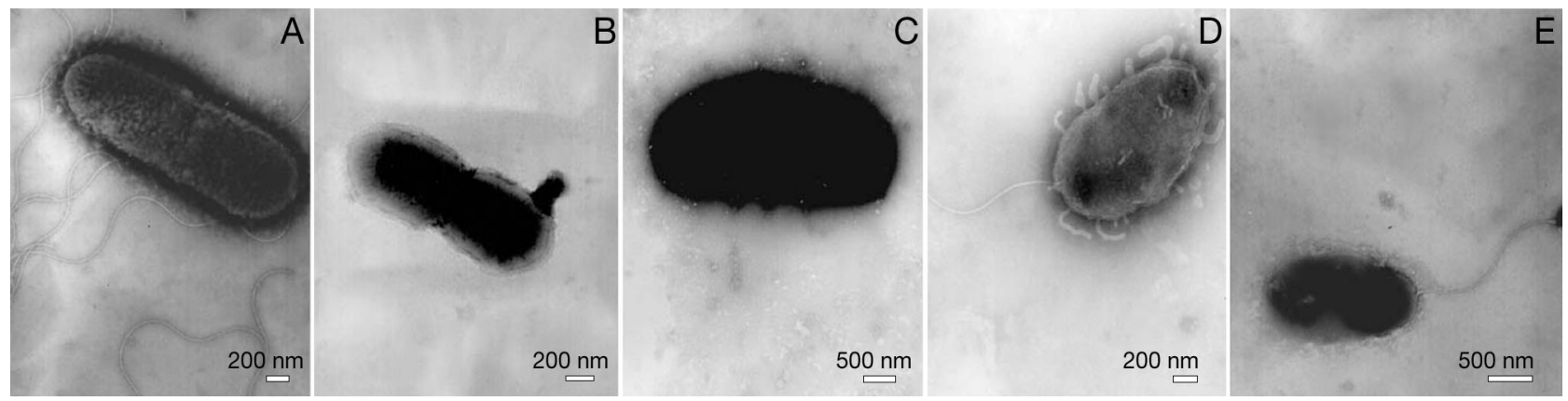

Fig. 2. Electron micrographs of representative strains after negative staining in TEM. (A) Serratia sp. (strain AP504), (B) Flavobacterium sp. (strain AP609), (C) Pseudoalteromonas sp. (strain AP631), (D) Shewanella sp. (strain AP629), (E) Vibrio spp. (strain AP722) 
Table 3. Comparison of physiological and biochemical characterization (+: positive; -:negative; \pm : some strains positive, and some negative) between isolates and reference strains. A: V. splendidus ATCC 33125; B: V. orientalis; C: V. nereis; E: Serratia odorifera biovar (data from Krieg \& Hoit 1994 and Dong \& Cai 2001); D: V. anguillarum HUFP5001 (present study); O-F: oxidationfermentation medium (F: fermentative; O: oxidative); O/129: 2,4-diamino-6, 7-diiso-propylpteridine; n: number of strains with the same biochemical characterization; nd: no data

\begin{tabular}{|c|c|c|c|c|c|c|c|c|c|c|c|c|c|}
\hline $\begin{array}{ll}\text { Characterization } & A \\
\text { variable } & \text { ( }\end{array}$ & $\begin{array}{l}\text { AP722 } \\
(\mathrm{n}=13)\end{array}$ & AP613 & AP508 & AP620 & AP504 & $\begin{array}{l}\text { AP611 } \\
(\mathrm{n}=4)\end{array}$ & AP619 & AP615 & A & B & $\mathrm{C}$ & $\mathrm{D}$ & E \\
\hline Gram & - & - & - & - & - & - & - & - & - & - & - & - & - \\
\hline Motility & + & + & + & + & + & + & + & - & + & + & + & + & + \\
\hline Oxidase & + & + & + & + & - & + & + & + & + & + & + & + & - \\
\hline Catalinase & + & + & + & + & + & + & + & + & + & + & + & + & + \\
\hline O-F test & $\mathrm{F}$ & $\mathrm{F}$ & $\mathrm{F}$ & $\mathrm{F}$ & $\mathrm{F}$ & $\mathrm{F}$ & $\mathrm{F}$ & $\mathrm{O}$ & $\mathrm{F}$ & $\mathrm{F}$ & $\mathrm{F}$ & $\mathrm{F}$ & F \\
\hline $\mathrm{H}_{2} \mathrm{~S}$ & - & - & - & - & - & - & - & - & - & - & - & - & - \\
\hline Citrate & + & - & + & + & + & + & + & + & + & - & + & + & + \\
\hline Nitrate & + & + & + & + & + & + & + & - & + & + & + & + & + \\
\hline Indole & + & + & - & - & + & + & + & + & + & + & - & - & nd \\
\hline Methyl red & + & + & + & + & + & + & + & + & + & + & + & + & + \\
\hline Voges Proskauer & + & - & - & + & + & + & - & + & + & - & - & + & nd \\
\hline$\beta$-galactosidase & + & + & + & + & + & - & - & + & + & + & + & + & + \\
\hline Galactose & + & + & + & + & + & + & + & - & + & + & + & + & + \\
\hline Urease & + & - & - & + & - & + & - & - & + & - & - & + & - \\
\hline Star & + & + & - & + & + & + & + & + & + & + & - & + & + \\
\hline Tween 80 & + & + & - & + & + & + & + & + & + & + & - & + & nd \\
\hline $4^{\circ} \mathrm{C}$ & \pm & + & - & - & + & - & + & + & \pm & + & - & - & nd \\
\hline $10^{\circ} \mathrm{C}$ & + & + & + & + & + & + & + & + & + & + & + & + & nd \\
\hline $35^{\circ} \mathrm{C}$ & + & + & - & + & + & + & + & + & + & + & - & + & nd \\
\hline $40^{\circ} \mathrm{C}$ & - & + & + & + & + & + & - & - & - & + & + & + & nd \\
\hline $0 \% \mathrm{NaCl}$ & + & - & - & + & + & + & + & - & + & - & - & - & nd \\
\hline $0.5 \%$ & + & - & + & + & + & + & + & - & + & - & + & + & nd \\
\hline $6 \%$ & + & + & + & + & + & + & + & - & + & + & + & + & nd \\
\hline $8 \%$ & + & + & + & + & + & + & + & - & + & + & + & + & nd \\
\hline $10 \%$ & - & + & + & + & + & - & - & - & - & + & + & + & nd \\
\hline Arginine & + & + & + & + & - & + & + & + & + & + & + & + & - \\
\hline Lysine & + & + & + & + & + & + & + & + & + & + & + & + & + \\
\hline Ornithine & - & - & - & - & + & - & - & - & - & - & - & - & + \\
\hline Arabinose & - & - & - & - & + & - & - & - & - & - & - & - & + \\
\hline Cellobiose & + & + & + & + & + & + & + & + & + & + & - & + & + \\
\hline Fructose & + & + & + & + & + & + & + & + & + & + & + & + & + \\
\hline D-Galactose & + & + & + & + & + & + & + & + & + & + & + & + & + \\
\hline D-Gluctose & + & + & + & + & + & + & + & + & + & + & + & + & + \\
\hline Inositol & - & - & - & - & - & - & - & - & - & - & - & - & - \\
\hline Lactose & \pm & - & - & - & + & - & - & - & \pm & - & - & + & + \\
\hline Maltose & + & + & + & + & + & + & + & + & + & + & + & + & + \\
\hline Mannitol & + & + & - & + & + & + & + & + & + & + & - & + & + \\
\hline Mannose & + & + & + & + & + & + & + & + & + & + & & & + \\
\hline Raffinose & - & - & - & - & + & - & - & - & - & - & - & - & + \\
\hline Rhamnose & \pm & - & - & + & + & + & - & - & \pm & - & - & + & + \\
\hline Sucrose & + & + & + & + & + & + & + & + & + & + & + & + & + \\
\hline Trehalose & + & + & + & + & + & + & + & - & + & + & + & + & + \\
\hline Xylitol & - & - & - & - & - & - & - & - & - & - & - & - & - \\
\hline TCBS & + & + & + & + & + & + & + & + & + & + & + & + & + \\
\hline $\begin{array}{l}\text { Salmonella Shigella } \\
\text { agar }\end{array}$ & $\mathrm{a}+$ & - & + & + & + & + & + & + & + & - & + & + & + \\
\hline MacConkey & + & - & + & + & + & + & + & + & + & - & + & + & + \\
\hline $\mathrm{O} / 129$ & + & - & + & + & + & + & + & + & + & - & + & + & + \\
\hline
\end{tabular}

tained from representative strains. The strain AP722 was a representative strain of Vibrio splendidus that had been amplified by VSPN-F and VSPN-R primers. Strains AP617, AP623, AP625 and AP722 belonged to $V$. splendidus with the similarity above $99 \%$ and bootstrap values of 66 to 97 . The strain AP616 clus- tered neither with $V$. splendidus (accession number: AJ874366) nor $V$. gigantis (accession number: EF094888), but similarities between them were 98.5 and $97.8 \%$, respectively. The strain AP616 showed difference in the utilization of fructose and rhamnose compared with $V$. splendidus (accession number: 
Table 4. Comparison of physiological and biochemical characterization between Pseudoalteromonas subspecies isolated from diseased sea cucumbers (strain AP631) and reference strain (IAM no.) data from Akagawa-Matsushita et al. (1992); nd: not detected

\begin{tabular}{|c|c|c|c|}
\hline $\begin{array}{l}\text { Characterization } \\
\text { variable }\end{array}$ & $\begin{array}{c}\text { P. haloplanktis } \\
\text { subsp. haloplanktis } \\
\text { IAM } 12951\end{array}$ & $\begin{array}{l}\text { P. haloplanktis } \\
\text { subsp. tetraodonis } \\
\text { IAM } 14160\end{array}$ & $\begin{array}{c}\text { Strain AP631 } \\
(\mathrm{n}=2)\end{array}$ \\
\hline Pigments & - & - & - \\
\hline Denitrification & - & - & - \\
\hline Starch & - & - & - \\
\hline Chitin & - & - & nd \\
\hline Agar & - & - & nd \\
\hline \multicolumn{4}{|l|}{ Growth at } \\
\hline $4^{\circ} \mathrm{C}$ & - & - & + \\
\hline $35^{\circ} \mathrm{C}$ & + & + & + \\
\hline D-Glucose & + & + & + \\
\hline Mannose & - & - & - \\
\hline Fructose & + & - & - \\
\hline Sucrose & - & + & + \\
\hline Maltose & + & + & + \\
\hline Cellobiose & - & - & - \\
\hline Lactose & - & + & + \\
\hline D-Galactose & - & + & + \\
\hline Pyruvate & + & + & + \\
\hline Fumarate & + & + & + \\
\hline Glycerol & - & - & nd \\
\hline Rhamnose & - & - & - \\
\hline Citrate & + & - & - \\
\hline
\end{tabular}

AJ874366). There were large differences on the utilization of fructose and rhamnose, urea hydrolysis, lysine decarboxylase activity and growth at 0 and $8 \% \mathrm{NaCl}$ (Le Roux et al. 2005) between the strain AP616 and V. gigantis (accession number: EF094888). The strain AP616 was identified as V. splendidus based on its biochemical and genetic characterization. Strains AP508, AP619 and AP611 were clustered with $V$. nereis, $V$. chagasii and other Vibrio sp., respectively. Strains AP401, AP614 and AP620 did not belong to any ribocluster (Fig. 3).

The strain AP526 showed high similarity to Shewanella sp. (95.2 to $100.0 \%$ ) and was clustered with Shewanella sp. clone 10 (accession number: AY785251). The similarity and bootstrap value between both strains were $100 \%$ (Fig. 4).

Strain AP631 showed high similarity $(99.07 \%)$ to the strain Pseudoalteromonas tetraodonis (accession number: AB257325) and had a bootstrap value of 100 (Fig. 5).

Table 5. Isolation percentages (\%) and pathogenicity of bacterial groups (31 strains) from diseased sea cucumbers from 2004 to 2006

\begin{tabular}{|c|c|c|c|c|c|}
\hline $\begin{array}{l}\text { Bacterial } \\
\text { group }\end{array}$ & $\begin{array}{l}\text { Percent } \\
\text { (no.) }\end{array}$ & $\begin{array}{l}\text { Strain } \\
\text { no. }\end{array}$ & $\begin{array}{c}\text { Infected twice } \\
(4.3-8.6) \times 10^{9} \text { cells } \mathrm{ml}^{-1} \\
\text { Average mortality }(\%)\end{array}$ & $\begin{array}{c}\text { Infected at third time } \\
(5.6-8.9) \times 10^{8} \text { cells } \mathrm{ml}^{-1} \\
\text { Mortality }(\%)\end{array}$ & $\begin{array}{c}\text { No. of } \\
\text { pathogens }\end{array}$ \\
\hline Vibrio & $64.51(20)$ & & & & 8 \\
\hline$V$. chagasii & $3.22(1)$ & AP619 & 30 & 10 & \\
\hline$V$. nereis & $3.22(1)$ & AP508 & 10 & 0 & \\
\hline$V$. orientalis & $3.22(1)$ & AP613 & 25 & 10 & \\
\hline \multirow[t]{14}{*}{ V. splendidus } & $41.9(13)$ & AP402 & 15 & 0 & \\
\hline & & AP403 & 100 & 90 & \\
\hline & & AP610 & 100 & 100 & \\
\hline & & AP611 & 100 & 90 & \\
\hline & & AP612 & 5 & 0 & \\
\hline & & AP616 & 100 & 80 & \\
\hline & & AP617 & 100 & 80 & \\
\hline & & AP618 & 100 & 90 & \\
\hline & & AP621 & 25 & 10 & \\
\hline & & AP622 & 100 & 90 & \\
\hline & & AP722 & 100 & 100 & \\
\hline & & AP623 & 20 & 0 & \\
\hline & & AP624 & 20 & 0 & \\
\hline & & AP625 & 10 & 0 & \\
\hline Vibrio spp. & $3.22(1)$ & AP401 & 15 & 0 & \\
\hline Vibrio spp. & $3.22(1)$ & AP614 & 25 & 10 & \\
\hline Vibrio spp. & $3.22(1)$ & AP615 & 15 & 0 & \\
\hline Vibrio spp. & $3.22(1)$ & AP620 & 10 & 0 & \\
\hline Flavobacterium & $3.22(1)$ & & & & $\mathbf{0}$ \\
\hline Flavobacterium sp. & $3.22(1)$ & AP509 & 5 & 0 & \\
\hline
\end{tabular}


Table 5 (continued)

\begin{tabular}{|c|c|c|c|c|c|}
\hline $\begin{array}{l}\text { Bacterial } \\
\text { group }\end{array}$ & $\begin{array}{l}\text { Percent } \\
\text { (no.) }\end{array}$ & $\begin{array}{c}\text { Strain } \\
\text { no. }\end{array}$ & $\begin{array}{c}\text { Infected twice } \\
(4.3-8.6) \times 10^{9}{\text { cells } \mathrm{ml}^{-1}}^{-1} \\
\text { Average mortality }(\%)\end{array}$ & $\begin{array}{c}\text { Infected at third time } \\
(5.6-8.9) \times 10^{8}{\text { cells } \mathrm{ml}^{-1}} \\
\text { Mortality }(\%)\end{array}$ & $\begin{array}{c}\text { No. of } \\
\text { pathogens }\end{array}$ \\
\hline Pseudoalteromonas & $6.45(2)$ & & & & 2 \\
\hline P. tetraodonis & $6.45(2)$ & $\begin{array}{l}\text { AP630 } \\
\text { AP631 }\end{array}$ & $\begin{array}{l}100 \\
100\end{array}$ & $\begin{array}{l}60 \\
60\end{array}$ & \\
\hline Serratia & $12.9(4)$ & & & & $\mathbf{0}$ \\
\hline S. odorifera biogroup I & $12.9(4)$ & $\begin{array}{l}\text { AP504 } \\
\text { AP505 } \\
\text { AP506 } \\
\text { AP507 }\end{array}$ & $\begin{array}{l}5 \\
0 \\
0 \\
0\end{array}$ & $\begin{array}{l}0 \\
0 \\
0 \\
0\end{array}$ & \\
\hline $\begin{array}{l}\text { Shewanella } \\
\text { Shewanella sp. }\end{array}$ & $\begin{array}{l}\mathbf{1 2 . 9}(\mathbf{4 )} \\
12.9(4)\end{array}$ & $\begin{array}{l}\text { AP526 } \\
\text { AP427 } \\
\text { AP428 } \\
\text { AP629 }\end{array}$ & $\begin{array}{c}100 \\
100 \\
30 \\
100\end{array}$ & $\begin{array}{c}100 \\
100 \\
10 \\
100\end{array}$ & 3 \\
\hline Total & $100(31)$ & & 13 & & \\
\hline
\end{tabular}

On the basis of phenotypic and genetic characterization, the bacterial diversity groups isolated from diseased sea cucumbers were identified as follows: (1) Vibrio spp. (64.5\%) as $V$. chagasii $(3.2 \%), V$. nereis $(3.2 \%), V$. orientalis (3.2\%), V. splendidus $(41.9 \%)$ and 4 strains unidentified to species level; (2) Shewanella sp. (12.9\%); (3) Serratia sp. as S. odorifera biogroup I $(12.9 \%) ;(4)$ Pseudoalteromonas sp. as P. tetraodonis $(6.4 \%) ;(5)$ Flavobacterium sp. (3.2\%) (Table 5).

\section{Pathogenicity assays}

Pathogen diversity in sea cucumbers

The results demonstrated that only 13 out of 31 strains showed virulence to sea cucumbers (Table 5). These strains belonged to Vibrio splendidus (8 strains: AP403 isolated from sediments, AP610 and AP611 from intestines, AP616, AP618 and AP622 from coelomic fluid, AP617 from body wall, and AP722 from ulcerated skin), Shewanella sp. (3 strains: AP526 and AP629 from coelomic fluid and AP427 from rearing water) and Pseudoalteromonas tetraodonis (2 strains: AP630 and AP631 from body wall). The clinical signs of diseased sea cucumbers infected naturally and artificially were similar and included viscera ejection (Fig. 1B), swollen mouth, (Fig. 1A), skin ulceration (Fig. 1C) and death (Fig. 1D). Viscera ejection and skin ulceration were the most common and swollen mouth was often observed. No typical signs appeared after infection by different strains. The inoculated strain was reisolated from moribund and newly dead individuals. No disease signs were noted in sea cucumbers in the control group.
Virulence of representative strains in sea cucumber

$$
\left(\mathrm{LD}_{50}\right)
$$

The 14 d LD 50 values of Vibrio splendidus (AP722), Shewanella sp. (AP629) and Pseudoalteromonas tetraodonis (AP631) were $1.74 \times 10^{7}, 7.76 \times 10^{6}$ and $7.24 \times$ $10^{7} \mathrm{CFU} \mathrm{g}^{-1}$ body weight of sea cucumber, respectively, after treatment by i.p. injection.

\section{Antimicrobial susceptibility}

The strains of Vibrio splendidus $(\mathrm{n}=9)$, Shewanella sp. $(\mathrm{n}=3)$, and Pseudoalteromonas tetraodonis $(\mathrm{n}=2)$ were resistant to penicillin $\mathrm{G}$, ampicillin, carbenicillin and amoxicillin, but were sensitive to cipiofloxacinum, neomycin, norfloxacin, althiomycin, SMZ+TMP (sulfamethoxazole + trimethoprim) and cefazolin. Both $V$. splendidus and $P$. tetraodonis were sensitive to cefazolin, but Shewanella sp. was resistant (Table 6).

\section{DISCUSSION}

Even though sea cucumber is one of the most important marine aquaculture species in China, the description of pathogens affecting this group is still limited. In the present study, we performed a survey from 2004 to 2006 to characterize bacterial pathogens affecting sea cucumber in China. In agreement with other studies in marine fishes (Anderson \& Conroy 1970, Austin \& Austin 1987, Austin et al. 1995), the most prevalent infectious bacterial pathogens affecting farmed sea cucumbers in China were Gram-negative bacteria. 


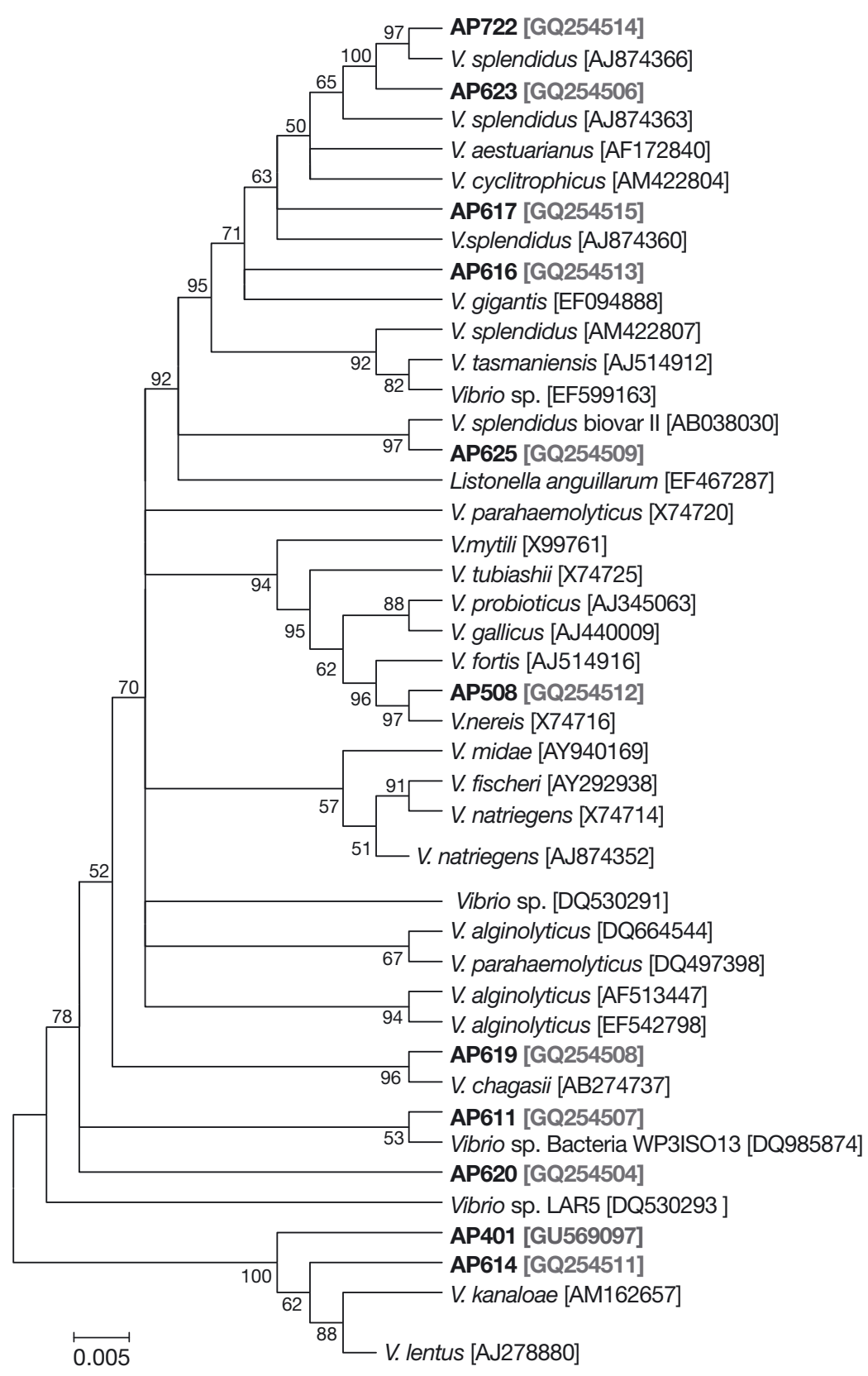

Fig. 3. Vibrio spp. Phylogenetic tree based on partial 16S rRNA gene sequences by maximum likelihood analysis. The dendrogram was constructed by the neighbor-joining method with the Mega 4.0 program. Only bootstrap values above $50 \%$ from 1000 replicates are shown. The scale bar represents 0.005 substitutions per nucleotide site

The bacterial genera with high incidence in diseased sea cucumbers during the study period were Vibrio $(64.5 \%)$, Shewanella $(12.9 \%)$ and Serratia $(12.9 \%)$. The bacterial diversity was different from that associated with hindgut of actively feeding Stichopus japonicus (Chang et al. 2004) and from the marine sedimentary environment, coelomic liquid and body surface of $S$. japonicus whose isolates belonged to the genera
Vibrio, Pseudomonas, Neisseria, Acinetobacter, Flavobacterium, Arthrobacter, Micrococcus, Xanthomonas, Corynebacterium, Caulobacter and Alcaligenes (Sun \& Chen 1989). The bacterial group from diseased sea cucumbers also differed from that found in asymptomatic individuals, which came from 8 genera: Vibrio $(62.71 \%)$, Enterobacteriaceae, Aeromonas, Pseudomonas, Agrobacteri, Moraxella, Acinetobacter, Alcaligenes and some Gram-positive strains $(3.39 \%)$. The frequency of Vibrio in diseased sea cucumbers appeared higher than that in asymptomatic sea cucumbers. Shewanella was only isolated from diseased sea cucumbers, but Pseudomonas, Aeromonas, Agrobacterium, Moraxella, Acinetobacter and Alcaligenes could not be isolated from symptomatic sea cucumbers.

The bacterial group in diseased sea cucumber was smaller compared with that in asymptomatic sea cucumber and other aquatic organisms. The isolated bacteria belonged to 5 genera which commonly infect other marine fish. Vibrio was the prominent genera (Balebona et al. 1998, Sakata 1989). In a survey of bacterial pathogens affecting farmed gilt-head sea bream Sparus aurata L. in southwestern Spain from 1990 to 1996, 208 isolates were obtained and 132 strains were verified to cause massive mortality and clinical symptoms (Batebona et al. 1998). The main isolates were Vibrio $(67.8 \%)$, Pseudomonas (13.5\%), Photobacterium damsela subsp. poscicida (6.7\%), Cytophaga/Flexibacter-like bacteria (4.8\%), Aeromonas $(0.5 \%)$, and some Grampositive bacteria (Balebona et al. 1998). The prominent genus found in both diseased sea cucumbers and gilt-head sea bream was Vibrio. Shewanella from diseased sea cucumbers are rough, Gram-negative, motile with polar flagellum, produce $\mathrm{H}_{2} \mathrm{~S}$ and grow well on regular culture mediums (present study). This genus includes more than 30 species (Holt et al. 2005), which have been considered as human and nonhuman pathogens (Brink et al. 1995, Butt et al. 1997, Bagge et al. 2001). Some studies demonstrated that Shewanella can transfer between aquatic animals and humans. Vogel et al. (2000) analyzed the homology 


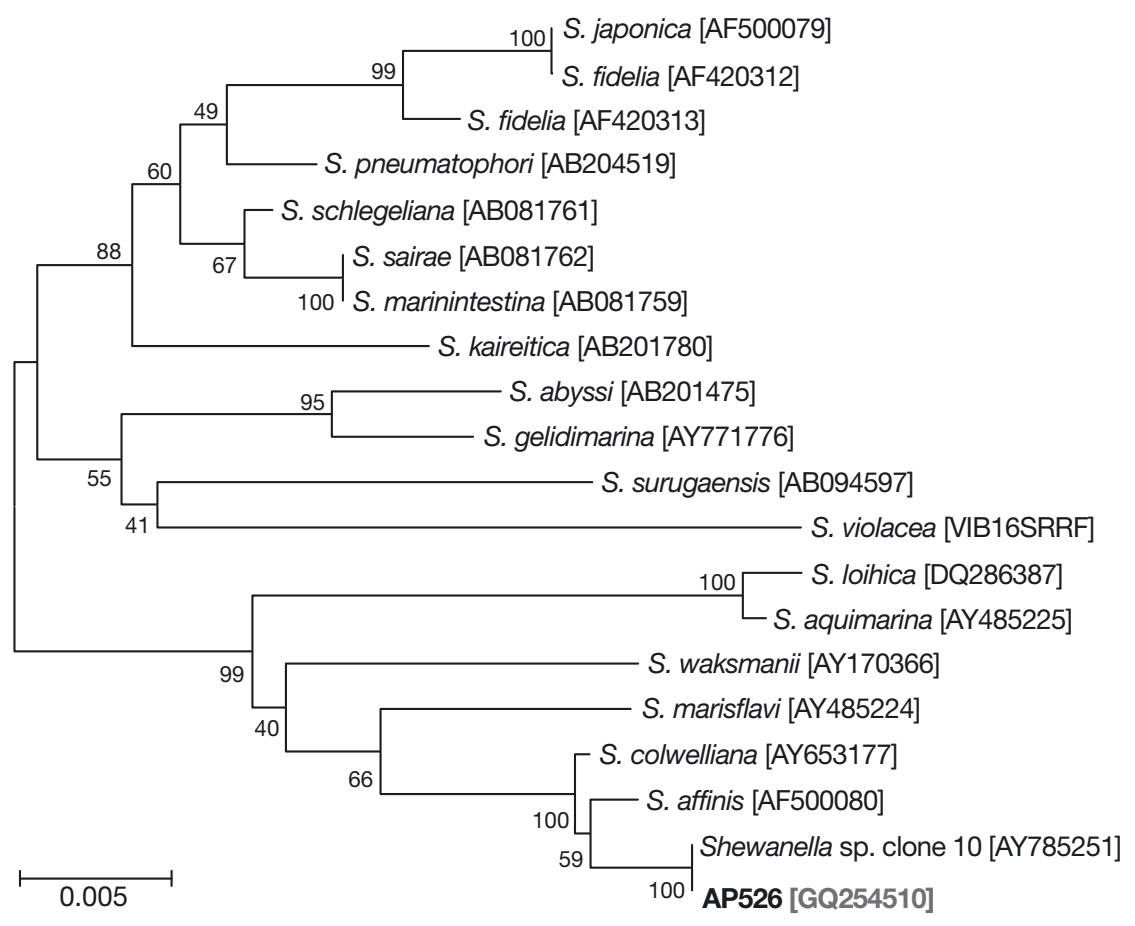

Fig. 4. Shewanella spp. Phylogenetic tree based on partial 16S rRNA gene sequences. See Fig. 3 for explanation of the construction of the dendrogram

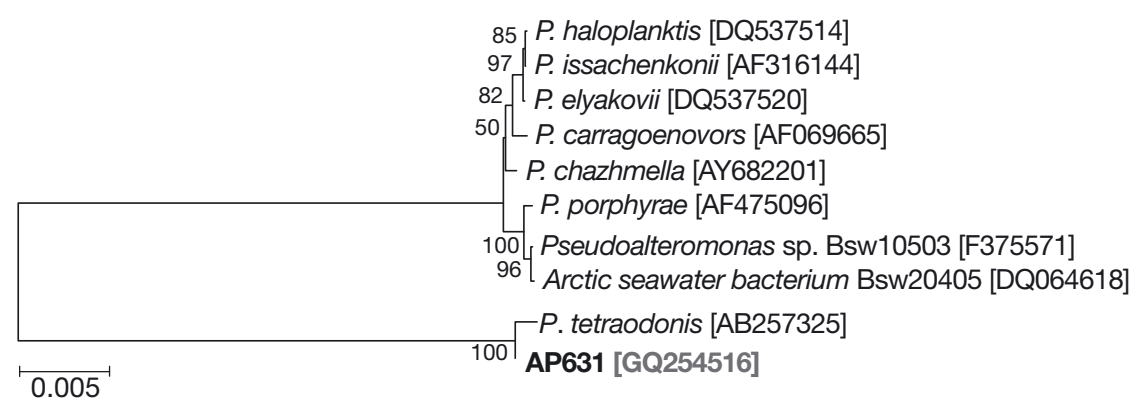

Fig. 5. Pseudoalteromonas spp. Phylogenetic tree based on partial 16S rRNA gene sequences. See Fig. 3 for explanation of the construction of the dendrogram nent genus, which included 5 species. Thirteen strains in the genus were identified as $V$. splendidus. $V$. splendidus was the prominent species, comprising $41.94 \%$ of all isolates (the number of $V$. splendidus/the number of heterotrophic bacteria) and $65 \%$ in the Vibrio genus (the number of $V$. splendidus/the number of all Vibrio spp.). $V$. splendidus grows in lower temperatures and is considered to be an opportunistic pathogen in seawater (Baticados et al. 1990, Myhr 1991, Castro et al. 1992, Paillard et al. 2004, Thompson et al. 2005, Xu et al. 2005, Slack et al. 2006). V. splendidus was the prominent bacterial pathogen associated with oysters when water temperatures were below $20^{\circ} \mathrm{C}$ (Pujalte et al. 1999). Koren \& Rosenberg (2006) studied bacteria isolated from mucus and tissues of coral in winter and summer and found V. splendidus was the prominent species $(68 \%)$ at a water temperature of $17^{\circ} \mathrm{C}$. V. splendidus was an opportunistic pathogen in sea cucumber and could be isolated from both diseased and asymptomatic sea cucumbers, with a higher chance of finding it in diseased individuals (present study, unpubl. data).

The biochemical characterization of Vibrio splendidus is diverse from one strain to another and depends on the ori-

between the clinical and environmental strains isolated from humans and seawater that patients had contact with, respectively, and found the same origin of Shewanella. Other studies (Nozue et al. 1992, Dominguez et al. 1996, Vogel et al. 2000) noted that more than $80 \%$ of patients with lower leg ulcers were infected by Shewanella while swimming in water containing the bacterium. Kim et al. (1989) also found a similar origin of isolates from patients and seawater. Shewanella isolated from diseased sea cucumbers could be related with human shewanellosis. However, further study is needed to confirm its true origin. The bacterial group associated with diseased sea cucumbers demonstrated Vibrio (20 strains) as the promi- gin of strains. The 13 isolates were identified as $V$. splendidus by phenotypic and genetic methods, but the acid production of rhamnose and fructose differentiated one strain from another, which agrees with the study by Gatesoupe et al. (1999). At the same time, 9 of 13 strains of $V$. splendidus identified by $16 \mathrm{~S}$ rRNA genes sequence could be amplified by VSPN-F and VSPN-R primers of $V$. splendidus. Since these primers of $V$. splendidus, designed by Lee et al. (2002), are not active for all $V$. splendidus strains, more efficient primers are needed for future study. The 16S rRNA gene sequences of bacteria were used to identify the bacteria, but some strains could not be identified to the species level. Although the 16S rRNA gene is consid- 
Table 6. Antibacterial activities of various antibiotics against bacterial pathogens. S: sensitive; I: intermediate; R: resistant

\begin{tabular}{|c|c|c|c|c|}
\hline \multirow{2}{*}{$\begin{array}{l}\text { Antibacterial } \\
\text { agent }\end{array}$} & \multirow{2}{*}{$\begin{array}{c}\text { Content } \\
\left(\mu \mathrm{g} \mathrm{slip}{ }^{-1}\right)\end{array}$} & \multicolumn{3}{|c|}{ Diameter of inhibiting ring (mm) (antibacterial activity) } \\
\hline & & $\begin{array}{l}\text { Vibrio splendidus } \\
\text { Strain AP722 }\end{array}$ & $\begin{array}{l}\text { Shewanella sp. } \\
\text { Strain AP629 }\end{array}$ & $\begin{array}{c}\text { Pseudoalteromonas tetraodonis } \\
\text { Strain AP631 }\end{array}$ \\
\hline Penicillin G & 10 & $-(\mathrm{R})$ & $-(\mathrm{R})$ & $-(\mathrm{R})$ \\
\hline Cipiofloxacinum & 5 & $22(\mathrm{~S})$ & $21(\mathrm{~S})$ & $30(\mathrm{~S})$ \\
\hline Kanamycin & 30 & $20(\mathrm{~S})$ & 15 (I) & $17(\mathrm{I})$ \\
\hline Neomycin & 30 & $20(\mathrm{~S})$ & $19(\mathrm{~S})$ & $21(\mathrm{~S})$ \\
\hline Norfloxacin & 10 & 23 (S) & $21(\mathrm{~S})$ & 26 (S) \\
\hline Ampicillin & 25 & $-(\mathrm{R})$ & $-(\mathrm{R})$ & $-(\mathrm{R})$ \\
\hline Carbenicillin & 25 & $-(\mathrm{R})$ & $-(\mathrm{R})$ & $-(\mathrm{R})$ \\
\hline Althiomycin & 15 & $29(\mathrm{~S})$ & $27(\mathrm{~S})$ & $35(\mathrm{~S})$ \\
\hline $\begin{array}{l}\text { Sulfamethoxazole }+ \\
\text { trimethoprim }\end{array}$ & 30 & $28(\mathrm{~S})$ & $25(\mathrm{~S})$ & $28(\mathrm{~S})$ \\
\hline Cefazolin & 30 & $23(\mathrm{~S})$ & $11(\mathrm{I})$ & $27(\mathrm{~S})$ \\
\hline Amoxicillin & 20 & $-(\mathrm{R})$ & $-(\mathrm{R})$ & $-(\mathrm{R})$ \\
\hline Gentamicin & 10 & $18(\mathrm{~S})$ & $16(\mathrm{~S})$ & $18(\mathrm{~S})$ \\
\hline Novobiocin & 30 & $17(\mathrm{I})$ & $17(\mathrm{I})$ & 17 (I) \\
\hline Amikacin & 30 & 15 (I) & 15 (I) & 15 (I) \\
\hline
\end{tabular}

ered to be the 'gold standard' for the identification and construction of the phylogenetic tree for bacteria, the 16S rRNA gene sequences of different species are highly conserved and difference among species is only 0.1 to $1.4 \%$, which is subject to $1 \%$ mutation every 5000 yr. One strain will be identified within the species when the similarity is more than $99 \%$, so there will be many strains unidentified to the species. In the present study, 14 strains were identified by their 16S rRNA gene sequence, but the other 4 strains cannot be identified. In that case, new standards, such as gyrB genes, can be used for strain identification (Zhou et al. 2007, Garnier et al. 2008).

The present results identified 13 virulent strains (41.94\%). Among them, 8 strains belonged to Vibrio splendidus $(61.54 \%$, the number of one species/the number of pathogens), 3 strains were Shewanella sp. $(20.38 \%)$ and 2 were Pseudoaltermona tetraodonis $(15.38 \%)$. V. splendidus occurrred at the highest frequency. This is the first report of Shewanella sp. being virulent for sea cucumber. Eight strains isolated from diseased turbot Scophthalmus maximus L. larvae were identified as $V$. splendidus by phenotypic characteristics, DNA-DNA hydration, RAPD analysis and 16S rRNA gene sequence (Gatesoupe et al. 1999). The pathogenicity tests of $V$. splendidus (8 strains) were performed at a water temperature of $15^{\circ} \mathrm{C}$. The result showed that 6 strains were pathogens for turbot larvae and caused massive mortality. $\mathrm{LD}_{50}$ values $(14 \mathrm{~d})$ of $V$. splendidus, Shewanella sp. and P. tetraodonis demonstrated that the virulence was different for species: Shewanella sp. $>V$. splendidus $>$ P. tetraodonis. According to the criteria of Santos et al. (1988), a strain is considered as highly virulent if $\mathrm{LD}_{50}$ values range from $1.7 \times 10^{4}$ to $1 \times 10^{6} \mathrm{CFU} \mathrm{g}^{-1}$ body weight; moderately virulent if values range from $1.4 \times 10^{6}$ to $1.8 \times 10^{7}$
CFU g ${ }^{-1}$ body weight and non-virulent if values are higher than $10^{8} \mathrm{CFU} \mathrm{g}^{-1}$ body weight. Shewanella sp. showed high virulence, while $V$. splendidus and $P$. tetraodonis showed moderate virulence. $\mathrm{LD}_{50}$ values of $V$. splendidus for sea cucumber were $1.74 \times 10^{7} \mathrm{CFU}$ $\mathrm{g}^{-1}$ body weight, which was higher than the $\mathrm{LD}_{50}$ values for Sparus aurata L., which ranged from $1.7 \times 10^{4}$ to $1.2 \times 10^{5} \mathrm{CFU} \mathrm{g}^{-1}$ body weight (Balebona et al. 1998). This difference indicates that sea cucumbers are more resistant to the bacterium. This resistance could be related to the life history of sea cucumbers, which live on sediment, organic detritus and carcasses in which they propagate (Zhang et al. 2004). The number of bacteria in the digestive tract of sea cucumbers could reach $10^{7}$ cells $\mathrm{ml}^{-1}$ (Sun \& Chen 1989). It is not clear why sea cucumbers have an ability to digest and resist bacteria. Further research is needed to explore the pathogenic mechanisms of bacteria and the resistance of sea cucumbers to bacterial pathogens.

Acknowledgements. This research was supported by grants from the National Key Projects, National Science and Technology Pillar Program during the 11th Five-Year Plan period (2006BAD09A01), National 908 Special Projects (908ZH-03), National Natural Science Foundation of China (30800853), and Science and Technology Project of Dalian (2004B1NC030; 2006B11NC109).

\section{LITERATURE CITED}

Akagawa-Matsushita M, Matsuo M, Koga M, Yamasato K (1992) Alteromonas atlantica sp. nov. and Alteromonas carrageenovora sp. nov., bacteria that decompose algal polysaccharides. Int J Syst Bacteriol 42:621-627

Alapide-Tendencia VA, Dureza LA (1997) Isolation of Vibrio spp. from Penaeus monodon (Fabricius) with red disease syndrome. Aquaculture 154:107-114 
Alsina M, Blanch AR (1994) A set of keys for biochemical identification of environmental Vibrio species. J Appl Bacteriol 76:79-85

Anderson IW, Conroy DA (1970) Vibrio disease in marine fishes. Am Fish Soc Spec Pub 5:266-272

Austin B, Austin DA (1987) Bacterial fish pathogens: diseases in farmed and wild fish. Ellis Horwood, Chichester

Austin B, Alsina M, Austin DA, Blanch AR and others (1995) Identification and typing of Vibrio anguillarum: a comparison of different methods. Syst Appl Microbiol 18: 285-302

> Bagge D, Hjelm M, Johansen C, Huber I, Gram L (2001) S. putrefaciens adhesion and biofilm formation on food processing surfaces. Appl Environ Microbiol 67:2319-2325

Balebona C, Zorrilla I, Moriñigo MA, Borrego JJ (1998) Survey of bacterial pathologies affecting farmed gilt-head sea bream (Sparus aurata L.) in southwestern Spain from 1990 to 1996. Aquaculture 166:19-35

Baticados MCL, Lavilla-Pitogo CR, Cruz-Lacierda ER, de la Pena LD, Suñaz NA (1990) Studies on the chemical control of luminous bacteria Vibrio harveyi and V. splendidus isolated from diseased Penaeus monodon larvae and rearing water. Dis Aquat Org 9:133-139

Becker P, Gillanb D, Lanterbecq D, Jangouxa M, Rasolofonirina R, Rakotovaod J, Eeckhauta I (2004) The skin ulceration disease in cultivated juveniles of Holothuria scabra. Aquaculture 242:13-30

Brink AJ, Van Straten A, Van Rensburg AJ (1995) Shewanella (Pseudomonas) putrefaciens bacteremia. Clin Infect Dis 20:1327-1332

Butt AA, Figueroa J, Martin DH (1997) Ocular infection caused by three unusual marine organisms. Clin Infect Dis 24:740

Castro D, Martinez-Manzanares E, Luque A, Fouz B, Moriñigo MA, Borrego JJ, Toranzo AE (1992) Characterization of strains related to brown ring disease outbreaks in southwestern Spain. Dis Aquat Org 14:229-236

Chang YQ, Ding J, Song J (2004) Biology and aquaculture of sea cucumber and sea urchin. China Ocean Press, Beijing

> Deng H, He CB, Zhou ZC, Liu C and others (2009) Isolation and pathogenicity of pathogens from skin ulceration disease and viscera ejection syndrome of the sea cucumber (Apostichopus japonicus). Aquaculture 287:18-27

> Dominguez H, Vogel BF, Gram L, Hoffmann S, Schaebel S (1996) Shewanella alga bacteremia in two patients with lower leg ulcers. Clin Infect Dis 22:1036-1039

Dong XZ, Cai SY (2001) A manual of identification of bacteria. Beijing Science Press, Beijing (in Chinese)

Garnier M, Labreuche Y, Nicolas JL (2008) Molecular and phenotypic characterizationof Vibrio aestuarianus subsp. francensis subsp. nov., a pathogen of the oyster Crassostrea gigas. Syst Appl Microbiol 31:358-365

Gatesoupe FJ, Lambert C, Nicolas JL (1999) Pathogenicity of Vibrio splendidus strains associated with turbot larvae, Scophthalmus maximus. J Appl Microbiol 87:757-763

Holt HM, Gahrn-Hansen B, Bruun B (2005) Shewanella algae and Shewanella putrefaciens: clinical and microbiological characteristics. Clin Microbiol Infect 11:347-352

Kim JH, Cooper RA, Welty WK, Harrell LJ, Zwadyk P, Klotman ME (1989) Pseudomonas putrefaciens bacteremia. Rev Infect Dis 11:97-104

> Koren O, Rosenberg E (2006) Bacteria associated with mucus and tissues of the coral Oculina patagonica in summer and winter. Appl Environ Microbiol 72:5254-5259

Krieg NR, Hoit JG (1994) Bergey's manual of systematic bacteriology, 9th edn. Williams and Wilkins Company, Baltimore, MD
Le Roux F, Goubet A, Thompson FL, Faury N, Gay M, Swings J, Saulnier D (2005) Vibrio gigantis sp. nov., isolated from the haemolymph of cultured oysters (Crassostrea gigas). Int J Syst Evol Microbiol 55:2251-2255

Lee SK, Wang HZ, Law SHW, Wu RSS, Kong RYC (2002) Analysis of the 16S-23S rDNA intergenic spacers (IGSs) of marine Vibrio for species-specific signature DNA sequences. Mar Pollut Bull 44:412-420

Myhr E (1991) Characterization of non-luminescent, psychrophilic Vibrio splendidus biovar I isolated from fish. Characterization of fish pathogenic bacteria. DSc thesis, Norwegian College of Veterinary Medicine

NCCLS (National Committee for Clinical Laboratory Standards) (2003) Performance standards for antimicrobial disk susceptibility tests. Approved standard, 8th edn. NCCLS Doc M2-A8. NCCLS, Wayne, PA

NCCLS (National Committee for Clinical Laboratory Standards) (2004) Performance standards for antimicrobial disk susceptibility testing. 14th Informational Supplement. NCCLS Doc M100-514. NCCLS, Wayne, PA

> Nieto TP, Toranzo AE, Barja JL (1984) Comparison between the bacterial flora associated with fingerling rainbow trout cultured in two different hatcheries in the north-west of Spain. Aquaculture 42:193-206

> Nozue H, Hayashi T, Hashimoto Y, Ezaki T, Hamasaki K, Ohwada K, Terawaki Y (1992) Isolation and characterization of Shewanella alga from human clinical specimens and emendation of the description of $S$. alga. Int J Syst Bacteriol 42:628-634

- Paillard C, Leroux F, Borrego JJ (2004) Bacterial disease in marine bivalves, a review of recent studies: trends and evolution. Aquat Living Resour 17:477-498

Pujalte MJ, Ortigosa M, Macián MC, Garay E (1999) Aerobic and facultative anaerobic heterotrophic bacteria associated to Mediterranean oysters and seawater. Int Microbiol 2:259-266

Reed LJ, Muench H (1938) A simple method of estimating fifty percent end points. Am J Hyg 27:493-497

Sakata T (1989) Microflora of healthy animals. In: Austin B, Austin DA (eds) Methods for the microbiological examination of fish and shellfish. Ellis Horwood, Chichester, p 141-163

Santos Y, Toranzo AE, Barja JL, Nieto TP, Villa TG (1988) Virulence properties and enterotoxin production of Aeromonas strains isolated from fish. Infect Immun 56: 3285-3293

Slack AT, Symonds ML, Dohnt MF, Lee D (2006) Identification of pathogenic Leptospira species by conventional or real-time PCR and sequencing of the DNA gyrase subunit B encoding gene. BMC Microbiol 6:95, doi:10.1186/14712180-6-95

Sun Y, Chen D (1989) The microbial composition of Stichopus japonicus and its physiological property. Oceanol Limnol Sin 20:300-307 (in Chinese with English abstract)

> Tamura K, Dudley J, Nei M, Kumar S (2007) MEGA4: molecular evolutionary genetics analysis (MEGA) software version 4.0. Mol Biol Evol 24:1596-1599

Thompson JR, Pacocha S, Pharino C, Klepac-Ceraj V and others (2005) Genotypic diversity within a natural coastal bacterioplankton population. Science 307:1311-1313

> Toranzo AE, Barja J, Colwell RR, Hetrick FM, Crosa JH (1983) Haemagglutinating, haemolytic and cytotoxic activities of Vibrio anguillarum and related Vibrios isolated from striped bass on the Atlantic coast. FEMS Microbiol Lett 18: $257-262$

> Vogel BF, Holt HM, Smidt PG, Bundvad A, Søgaard P, Gram L (2000) Homogeneity of Danish environmental and clini- 
cal isolates of Shewanella algae. Appl Environ Microbiol 66:443-448

Weisburg WG, Barns SM, Pelletier DA, Lane DJ (1991) 16S ribosomal DNA amplification for phylogenetic study. J Bacteriol 173:697-703

Xu M, Wang P, Wang FP, Xiao X (2005) Microbial diversity at a deep-sea station of the Pacific nodule province. Biodivers Conserv 14:3363-3380

> Yoon JH, Yeo SH, Kim IG, Oh TK (2004) Shewanella marisflavi sp. nov. and Shewanella aquimarina sp. nov., slightly halophilic organisms isolated from sea water of the Yellow

Editorial responsibility: Mike Hine,

Fouras, France
Sea in Korea. Int J Syst Evol Microbiol 54:2347-2352

Zhang CY, Wang YG, Rong XJ, Sun HL, Dong SG (2004) Natural resources, culture and problems of sea cucumber worldwide. Mar Fish Res 25:89-93

Zhang CY, Wang YG, Rong XJ (2006) Isolation and identification of causative pathogen for skin ulcerative syndrome in Apostichopus japonicus. J Fish China 30:118-123

Zhou S, Hou Z, Li N, Qin Q (2007) Development of a SYBR Green I real-time PCR for quantitative detection of Vibrio alginolyticus in seawater and seafood. J Appl Microbiol 103:1897-1906

Submitted: September 29, 2009; Accepted: June 21, 2010

Proofs received from author(s): September 6, 2010 